DOI: https://doi.org/10.31933/dijemss.v3i2

Received: 10 November 2021, Revised: 17 December 2021, Publish: 25 January 2022

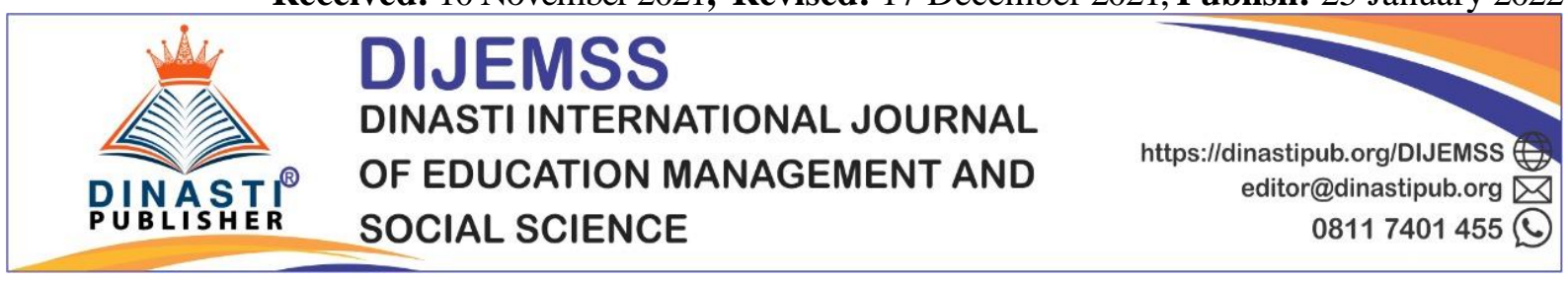

\title{
IMPORTANCE OF ORGANIZATIONAL COMMITMENT, MOTIVATION AND INCENTIVES IN IMPROVING EMPLOYEE PERFORMANCE
}

\author{
Darmin Darmin 1 , Abdullah Muksin², Yosandy Yulius ${ }^{3}$ \\ ${ }^{1}$ UPI YAI, Jakarta, Indonesia, darmin121965@gmail.com \\ ${ }^{2}$ UPI YAI, Jakarta, Indonesia, abydudung63@ gmail.com \\ ${ }^{3}$ UPI YAI, Jakarta, Indonesia, yosandi1968@gmail.com
}

\section{Corresponding Author: First Author}

Abstract: The purpose of this reseach was to determine the Effect of Motivation, Incentives and Organizational Commitment on Employee Performance of Garment companies in north jakarta. The research method is descriptive method. The sampe ini this reseach amounted to 107 respondents of Garment companies in north jakarta employees. Data processing uses quantitative data analysis using SPSS 25.0 for windows. The results showed that the determinant coefficient (Adjuster R Square) of 0.772 means that the variables of Motivation, Incentives and Organizational Commitment together contributed to the Performance of $77.2 \%$, the remaining $22.8 \%$ were other variables not in the model. The results of multiple regression show that both Motivation, Incentive and Organizational Commitment variables have a positive influence on Employee Performance. Significant value of 0,000<0,005 and Fcount $>$ Ftable $(71,162>2,761)$ which means that there is a significant relationship between Motivation, Incentives and Organizational Commitment and Employee Performance.

Keywords: Organization commitmen, Motivation, Incentives, Employee Performance

\section{INTRODUCTION}

Human resources (HR) is a very important asset in a company, and is a very valuable corporate asset. It is said to be very valuable because HR is the determining factor of the success of a company. The development of science and technology (SCIENCE AND TECHNOLOGY), the advancement of civilization, education and the demands of competition both in products and services, quality human resources are needed, because in quality human resources can determine the survival and development of a company.

Motivation must be from within the employee himself. Willpower, hard will and awareness of having a strong determination is the main key to an employee to achieve a position or position in the company that is dreamed so that it can cause job satisfaction for the 
employee itself.

Organizational commitment can be created if individuals in the organization are aware of their rights and obligations in the organization regardless of position and position, this is because the achievement of organizational goals is the result of the work of all members of the organization that are collective.

Good motivation from the company can make employees happy, comfortable, and passionate in work. Motivation is a driving force that causes a member of the organization to willingly and willingly exert ability in the form of expertise or skills, energy and time to organize various activities for which he is responsible and fulfill his obligations.

The purpose of providing incentives is to retain employees and increase their work motivation and work excitement, so that employees are encouraged to achieve more and ultimately can increase employee work productivity in order to achieve the company's goals that have been set.

Performance in an organization is the answer to the success or not of the organization's goals that have been set. Bosses or managers often don't pay attention unless it's very bad or things go awry. Too often managers don't know how poorly performance has slumped so companies/agencies face serious crises. The organization's bad impressions are profound and ignore the warning signs of declining performance.

Good human resource management will have a positive impact in order to meet sales targets to get employee performance benefits / bonuses, given the importance of improving employee performance, Garment Companies must be able to improve the performance of its employees, so it takes the right effort and strategies in optimizing human resources such as motivating, optimizing incentives and optimizing oganization commitment to human resources to support employee performance.

Based on the description above, the main problem in research is whether organizational commitment, motivation, and incentives have an effect in improving employee performance, where the analysis unit is germen companies in north Jakarta.

\section{REVIEW OF THEORY}

\section{Organizational Commitment}

According to Robbins and Judge (2009: 100) organizational commitment is as a situation where an employee sided with a particular organization as well as the goals of that employee and the desire to maintain membership in the organization.

According to Luthans (2006) organizational commitment is a strong desire to remain as a member of a particular organization, a desire to strive in accordance with the organization's wishes and certain beliefs as well as acceptance of organizational values and goals.

According to Mathis and Jackson in Sopiah (2008: 155) defines organizational commitment as the degree to which employees believe and are willing to accept organizational goals and will remain or will not leave the organization.

Mowday quoted by Sopiah (2008) said there are three aspects of commitment, among others:

1) Effective Commitment (Affective commitment) 
It has to do with the desire to be attached to the organization. Individuals settle in organizations of their own accord. The key to this commitment is to want to

2). Continuance commitment is a commitment based on rational needs. In other words, this commitment is formed on the basis of profit and loss, considered for what must be sacrificed when going to settle in an organization. The key to this commitment is the need to survive.

Normative commitment is a commitment that is based on norms that exist in employees, containing individual beliefs of responsibility towards the organization. He felt he had to endure because of loyalty. The key to this commitment is the obligation to stay in the organization (ought to).

Meanwhile, Minner in Sopiah (2008) proposed four factors that affect employee commitment, among others:

1). Personal factors, such as age, gender, level of education, and personality.

2). Job characteristics, such as the scope of the job, challenges in the job, conflict of roles, the level of difficulty in the work

3). Structural characteristics, such as the smallness of the organization, the shape of the organization, the presence of trade unions, and the level of control that the organization performs on employees

4). Work experience. An employee's work experience greatly affects the level of employee commitment to the organization. Employees who have only been working for several years and employees who have worked in the organization for decades certainly have a different level of commitment.

\section{Motivation}

Motivation comes from the Latin "movere" which means to move. Employee work motivation is a need that arises from within an employee who is influenced by internal and external factors to do a good job in the company. A useful need theory to motivate employees at work.

According to Robbins (2008: 222) motivation as a process that explains the intensity, direction, and perseverance of an individual to achieve his goals.

According to Hasibuan (2012: 141) motivation questioned how to direct the power and potential of subordinates, in order to work together productively successfully achieve and realize the goals that have been determined.

According to Siagian (2009: 102), stated that motivation is the driving force for someone to make the most contribution possible for the success of the organization to achieve its goals.

Based on the description of the opinions of the experts above, it can be concluded that motivation is a push or stimulant that makes a person do the job he wants willingly without feeling compelled to work together to make the maximum contribution possible for the success of the organization to achieve its goals.

Maslow's Theory of Hierarchy in Robbins and Judge (2009: 230) suggests that there are 5 (five) devices of need arranged in a hierarchical order, including: 
1) Physiological needs (Physiological Needs)

It's the most basic need. Examples are clothing/ clothing, food / food, boards / houses, and biological needs such as breathing and so on.

2). Safety and Security Needs

The need for protection from threats, dangers, contradictions. Examples such as: Free from colonization, free from threats, free from pain, free from terror, and so on.

3) Social Needs

The need to feel possessed is the need to be accepted into a group, interact and the need to love and be loved, for example is to have friends, have family, love needs of the opposite sex, and others.

4). Esteem Needs

The need to be respected and appreciated by others, examples: praise, charters, merits, gifts, and more.

5). Self-Actualization Needs

The need to use ability, skill, potential, need to argue, by putting forward ideas, giving judgment and criticism of something.

\section{Incentive}

Incentives as a means of motivation that encourage employees to work optimally, which is intended as extra income beyond the salary or wages that have been determined. Incentives are intended to meet the needs of employees and their families. The term incentive system is generally used to describe wage payment plans that are directly or indirectly associated with various standards of employee performance or organizational profitability. Incentives can be formulated in return for adequate services to employees whose performance exceeds established standards. Incentives are a motivating factor for employees to work better so that employee performance can improve.

According to Hasibuan (2012: 117) Incentives are additional services provided to certain employees whose achievements are above standard achievement. This incentive is a tool used by supporters of the principle of fairness in the provision of compensation.

According to Pangabean (2005:77) Incentives are direct rewards given to employees because achievement exceeds predetermined standards. Assuming that money can encourage employees to work harder, then those who are productive like their salary is paid based on the results of work.

According to Mangkunegara (2009: 89) Incentives are a form of motivation expressed in the form of money on the basis of high performance and is also a sense of recognition on the part of the organization to employee performance and contribution to the organization (company).

According to Siagian (2009:268) the types of incentives are:

1). Piece Of Work (wages per output)

Is a technique used to encourage employee performance based on the results of employee

work expressed in the number of production units.

2). Bonuses (Bonuses) 
It is an incentive given to employees who are able to work in such a way that the standard level of production is exceeded.

3). Commisions (commissions)

Is a bonus received for successfully carrying out the task and often applied by salespeople.

4). Executifes insentives (Incentives for Executives)

Is an incentive given to employees, especially managers or employees who have a high position in a company, for example to pay installments of homes, motor vehicles or children's education costs.

5). Maturity curve (Kurva Kematangan)

Is the incentive given to the workforce because of the working period and rank and salary cannot reach higher rank and income, for example in the form of scientific research or in the form of a greater teaching burden and so on.

6). Group incentive plan

It is a fact that in many organizations, performance is not due to individual success but because of the success of a working group capable of working as a team.

While according to Hasibuan (2009: 184) the types of incentives can be divided into three, namely:

1). Financial Incentives

That is the stimulant power given to employees based on their work performance in the form of money or goods. Can be given in the form of:

a). Bonus.

This is an additional salary given to employees above the value of their salary. Bonuses can be used as a reward for achieving specific goals set by the company or its dedication to the company.

b) Commission.

Is a type of bonus that will be paid to the sales party that results in sales that exceed the target.

c) Profit sharing.

It is an incentive received by the employee taken from the net income share.

d). Deferred compensation

There are two types of service programs that are paid in the future, namely:

1) Retire

Retirement has an incentive value because it meets a person's basic needs, which is to provide economic guarantees after he is no longer working.

2). Contractual Payments

An agreement between the leader and the employee, in which the employee after the completion of the working period is paid a certain amount of money over a certain period of time.

2). Non-Financial Incentives

That is, the existence of stimulants given to employees in the form of awards or confirmation based on their work performance. Can be given in the form of: 

A) Social security.
b) Award charter.
c). Promotion.
d). Giving oral or written compliments.

\section{3). Social Incentives}

That is the giving of dayaperangsangerangsang

to employees based on their work performance in the form of facilities and opportunities to develop their abilities. It can be given in the form of: promotion, following education, hajj and so on.

\section{Performance}

Performance according to Mangkunegara (2009:67)is the result of work in quality and quantity achieved by an employee in carrying out his duties in order to the responsibilities given to him.

Performance according to Sedarmayanti (2011:260) is a translation of performance which means the work of a worker, a management process or an organization as a whole where the results of the work must be able to show concrete and scalable evidence (compared to the standards that have been determined.)

Performance According to Rivai (2010: 309) is a function of motivation and ability. To complete a task or work one should have a certain degree of willingness and level of ability. Employee performance is very important in the company's efforts to achieve its goals.

Performance indicators according to Mangkunegara (2009: 75), namely:

1). Quality

The quality of work is how well an employee does what should be done, usually measured through accuracy, accuracy, skills, cleanliness of work results, the interconnectedness of work results by not ignoring the volume of work and the perfection of tasks on employee skills and abilities. The existence of good quality work can avoid the level of error, in the completion of a job that can be beneficial to the progress of the company.

2). Quantity

The quantity of work is how long an employee works in one day, this quantity of work can be seen from the speed of work of each employee, in addition it is also the amount produced expressed in terms such as the number of units, the number of cycles of activity completed. Shows the number of types of work done at a time so that efficiency and effectiveness can be carried out in accordance with the company's goals.

3). Execution of tasks

Task execution is how far employees are able to do their work accurately or there are no mistakes. which consists of a reliability component in completing tasks and knowledge of the work, in addition each employee must work in accordance with the tasks, functions and roles, expertise and competencies of each to achieve the vision, the mission and program of the organization's work that has been established.

4). Responsibility 
Responsibility for work is an awareness of the employee's obligation to carry out the work provided by the company, in addition to the ability of a workforce in completing tasks and work submitted to him as well as possible and on time and dare to assume the risk of the decisions he takes or actions he takes.

Performance Dimensions According to Wirawan (2009: 54) are grouped into three types, namely:

1). Work Results

It is the output of labor in the form of goods and services that can be calculated and measured in quantity and quality. Examples such as accuracy in carrying out work, quantity of product results, quality of product results and others.

2). Work Behavior

It is employee behavior that has to do with work, such as customer-friendly, behavior that is hinted at by organizational regulations, work discipline, thoroughness in work, professionalism, cooperation, leadership in the work team and utilizing time.

3). Personal Nature

It is a trait that has to do with work, this personal nature is necessary for employees in carrying out their work. Examples are skills, knowledge, honesty, cleanliness, courage, initiative, adaptability, intelligence and others.

According to A. Dale Timple quoted by Mangkunegara (2009: 15) performance factors consist of 2 factors, namely:

1). Internal factors

It is a factor that is associated with a person's traits.

2) External factors

These are factors that affect a person's performance that comes from the environment. Such as the behavior, attitudes, and actions of colleagues, subordinates or leaders, work facilities, and the organizational climate.

\section{Hypothesis}

$\mathrm{H1}$ :To examine the effect of organizational commitment to improve employee performance

H2: To research the effect of motivation on improving employee performance

H3:To research the effect of Incentives on employee performance improvement

$\mathrm{H}_{4}$ : To examine the influence of organizational commitment, motivation, and incentives and jointly in improving employee performance

\section{Framework of Thought}




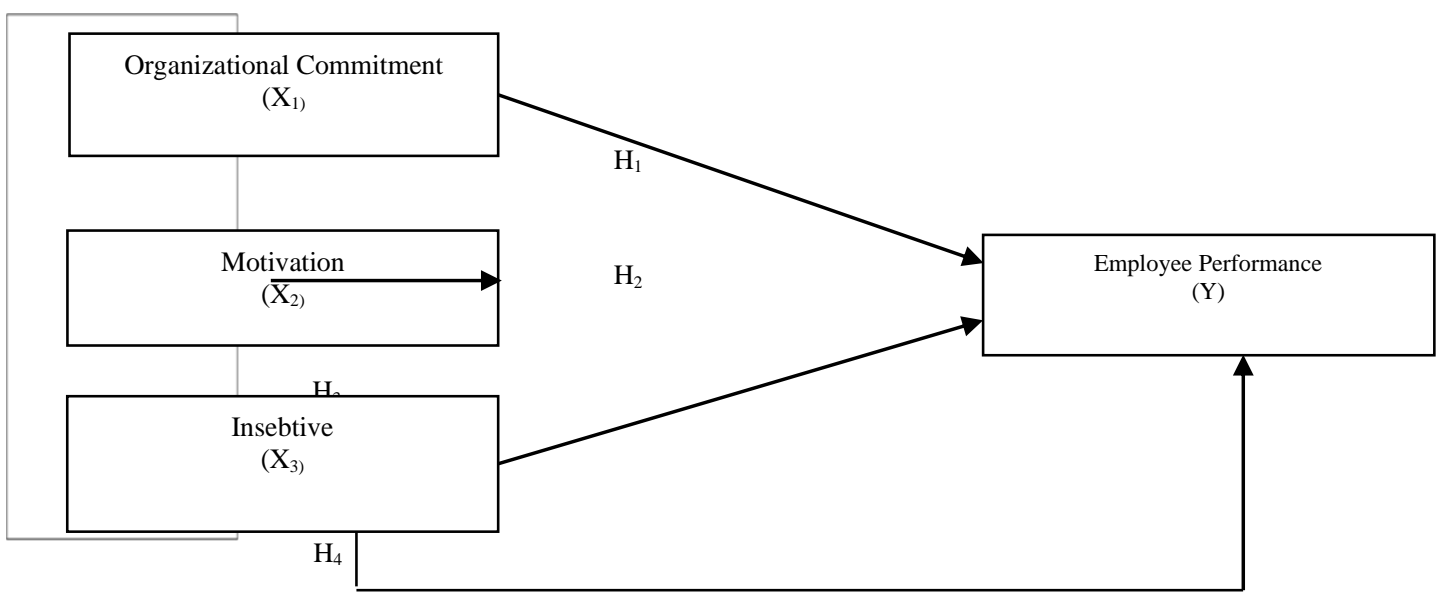

\section{RESEARCH METHODS}

The method used in this research is descriptive research method using quantitative approach with associative research type.

\section{Population and Sample}

The population in this study is all employees of Germen companies in north Jakarta which amounted to 63 employees. The sample used amounted to a population of 63 people, thus this sample used a saturated sample.

\section{RESULTS OF RESEARCH AND DISCUSSION}

1. Koefisien Multiple Correlation Between Organizational Commitment Variables, Motivation, and Incentives in improving Employee Performance.

Multiple Correlation Test Results

\begin{tabular}{|c|c|c|c|c|}
\hline & $\mathrm{R}$ & $\mathrm{R}$ Square & Adjusted R Square & Std. Error of the Estimate \\
\hline 1 & $.885^{\mathrm{a}}$ & .783 & .772 & 1.53522 \\
\hline
\end{tabular}

Predictors: (Constant), Komitmen_Organisasi, Motivation, Incentives

b. Dependent Variable: Kinerja_Karyawan

Primary Data, 2018

Correlation between Organizational Commitment, Motivation, Incentives in improving Employee Performance by 0.885 which means very strong and positive, if the variables of Organizational Commitment, Motivation, Incentives, and Employee Performance together increase then Employee Performance will also increase or vice versa.

\section{Multiple dete coefficient}

Based on the results of data processing it can be seen that the value of the coefficient of determination that has been adjusted (Adjuster R Square) is 0.772 That is, the contribution given by independent variables organizational commitment, motivation, and 
incentives is $77.2 \%$ to the dependent variable of employee performance. The remaining $22.8 \%(100-77.2 \%)$ is explained by other variables beyond the variables used.

\section{Multiple Regression Test}

Multiple Linear Regression Tests of Organizational Commitment Variables $\left(\mathbf{X}_{1}\right)$, Motivation ( $\left.\mathbf{X}_{2}\right)$, and Incentives (X3) in improving Employee Performance (Y).

Multiple linear regression is used to determine the influence between independent variables (Motivation, Incentives, and Organizational Commitments) simultaneously or simultaneously on dependent variables i.e. employee performance. Here are the results of multiple linear regression calculations using SPSS25.0 for windows:

\section{Multiple Linear Regression Analysis}

Coefficients $^{\mathrm{a}}$

\begin{tabular}{|c|c|c|c|c|c|}
\hline \multirow[t]{2}{*}{ Type } & \multicolumn{2}{|c|}{ Unstandardized Coefficients } & \multirow{2}{*}{$\begin{array}{l}\text { Standardized } \\
\text { Coefficients }\end{array}$} & \multirow[t]{2}{*}{$\mathrm{t}$} & \multirow[t]{2}{*}{ Sig. } \\
\hline & B & Std. Error & & & \\
\hline (Constant) & 7.724 & 2.451 & & 3.151 & .003 \\
\hline Motivation & .330 & .050 & .486 & 6.593 & .000 \\
\hline 1 Incentive & .196 & .050 & .271 & 3.891 & .000 \\
\hline $\begin{array}{l}\text { Commitment } \\
\text { Organization }\end{array}$ & . 311 & .055 & . 378 & 5.679 & .000 \\
\hline
\end{tabular}

a. Dependent Variable: Employee_Performance

Primary Data, 2018

\section{Data $P$}

From the table above shows that the regression equation obtained from the results of the analysis is:

$$
\begin{gathered}
Y=a+b_{1} X_{1}+b_{2} X_{2}+b_{3} X_{3} \\
Y=7,724+0.311 X_{1}+0.196 X_{2}+0.330 X_{3}
\end{gathered}
$$

The above equation has the meaning:

a). Constant coefficient $\mathrm{a}=7.724$ means that if the Variable Commitment of Organization, Motivation, Incentive, (independent) is considered constant, then employee performance (Y) is 7,724 . 
b). The regression coefficient of the Organization Commitment is 0.311 , this means that each addition of one value to the Organization Commitment while the other variable remains, it will cause an increase in employee performance of 0.311 .

b). The motivation regression coefficient of 0.330 , this means that each addition of one value to the motivation while the other variable remains, it will cause an increase in employee performance by 0.330 .

c). The Incentive regression coefficient of 0.196 , this means that each addition of one value to the Incentive while the other variable remains, it will lead to an increase in employee performance of 0.196 .

\section{Statistical Test $\mathbf{t}$}

The statistical test $\mathrm{t}$ basically shows how far the influence of an independent vaiabel (X) individually in describing dependent variables (Y). Decision making is based on the comparison of the values $t$ calculate each - each coefficient of regesi with the value $t$ of the table according to the level of significance used 0.05 (5\%). To find a distribution table i.e. with $\mathrm{df}(\mathrm{n}-\mathrm{k})=59$ and with two $\operatorname{sides}(a=0.025)$ obtained atable $\mathrm{t}$ value of 2,001. The following are the variable hypotheses of organizational commitment, motivation and incentives towards improving employee performance individually (partially) are as follows:

\section{Organizational Commitment}

H1Testing, The Effect of Organizational Commitment to Improve Employee Performance.

$\mathrm{H}_{03}: \quad \beta=0$ means that it does not have a significant influence between organizational commitment to employee performance.

$\mathrm{H}_{\mathrm{a} 3}: \beta \neq 0$ means that it has a significant influence between organizational commitment to employee performance.

Based on the results of regression analysis obtained $t_{\text {calculate }}>t$ table $(5,679>2,001)$ and significant value (Sig) $0.00<0.05$. It can then be concluded that $\mathrm{H}_{03}$ was rejected and $\mathrm{H}_{\mathrm{a} 3}$ was accepted. This shows that organizational commitment has a significant influence on employee performance.

\section{Motivation}

H1 Testing, The Effect of Motivation On Improving Employee Performance.

Based on the results of regression analysis obtained $t_{\text {calculate }}>t$ table $(6,593>2,001)$ and significant value (Sig) $0.00<0.05$. It can then be concluded that $\mathrm{H}_{01}$ was rejected and $\mathrm{H}_{\mathrm{a} 1}$ was accepted. This shows that motivation has a significant influence on employee performance.

\section{Incentive}

$\mathrm{H}_{2}$ Testing, The Effect of Incentives onImproving Employee Performance. 
$\mathrm{H}_{02}: \quad \beta=0$ means that it does not have a significant influence between Incentives on Employee Performance.

$\mathrm{Ha}_{2}: \quad \beta \neq 0$ means that it has a significant influence between Incentives to Employee Performance.

Based on the results of regression analysis obtained $t_{\text {calculate }}>t$ table $(3,891>2,001)$ and significant value $(\mathrm{Sig}) 0.00<0.05$. It can then be concluded that $\mathrm{H}_{02}$ was rejected and $\mathrm{Ha}_{2}$ was accepted. This shows that incentives have a significant influence on employee performance.

\section{Organizational Commitment}

\section{$\mathrm{H}_{3}$ Testing, The Effect of Organizational Commitment to Improve Employee Performance.}

$\mathrm{H}_{03}: \quad \beta=0$ means that it does not have a significant influence between organizational commitment to employee performance.

$\mathrm{H}_{\mathrm{a} 3}: \beta \neq 0$ means that it has a significant influence between organizational commitment to employee performance.

Based on the results of regression analysis obtained $t_{\text {calculate }}>t$ table $(5,679>2,001)$ and significant value $(\mathrm{Sig}) 0.00<0.05$. It can then be concluded that $\mathrm{H}_{03}$ was rejected and $\mathrm{H}_{\mathrm{a}}$ was accepted. This shows that organizational commitment has a significant influence on employee performance.

\section{Statisti F Test}

Simultaneous testing is intended to determine whether all free variables have the same effect on related variables. Tests are conducted using test F, if Fhitung > Ftabel then reject the null hypothesis (HO) and accept the alternative hypothesis ( $\mathrm{Ha})$, which means all free variables together have a concern against the bound variable.

On this hypothesis, what will be tested is whether organizational motivation, incentives and commitments together have a significant influence on employee performance variables.

$\mathrm{H} 0: \beta 1=\beta 2=\beta 3=0$

This means that it does not have a significant influence between motivation, incentives and organizational commitment to employee performance.

$\mathrm{Ha}_{4}: \beta 1 \neq \beta 2 \neq \beta 3 \neq 0$

This means that it has a significant influence between motivation, incentives and organizational commitment to employee performance.

\section{Satistic Test Results F}

\begin{tabular}{|c|c|c|c|c|c|}
\hline \multicolumn{6}{|c|}{ ANOVA $^{\mathrm{a}}$} \\
\hline Type & Sum of Squares & Df & Mean Square & $\mathrm{F}$ & Sig. \\
\hline Regression & 503.165 & 3 & 167.722 & 71.162 & $.000^{\mathrm{b}}$ \\
\hline 1 Residual & 139.057 & 59 & 2.357 & & \\
\hline Total & 642.222 & 62 & & & \\
\hline
\end{tabular}

a. Dependent Variable: Kinerja_Karyawan

b. Predictors: (Constant), Komitmen_Organisasi, Motivation, Incentives

Based on the results of the ANOVA test in the table above, the number $F_{\text {counted }} 71,162$ 
andthe value $F_{\text {table }}$ of 2,761 at the signification point or $4-1=3$ and df 2 (n-k-1) or 63-3-1 = 59 , so the value $F_{\text {calculated }}>F_{\text {table }}(71,162>2.761)$ with a probability of signification of $0,000<0.005$ then stated siginification and $\mathrm{H}_{\mathrm{a}}$ Accepted. It can be concluded that the Commitment of Organiation, Motivation, and Incentives togetherhas a positive and significant influence on employee performance.

\section{CONCLUSION}

1. There is an influence on organizational commitment to the improvement of employee performance.

The test results of organizational commitment variables have a positive effect because they have a significance value below the level of significance. This shows that organizational commitment is proven to have a positive and significant effect on employee performance. These results show that companies that have high motivation will have good employee performance.

2. There is a motivating influence on employee performance.

The results of the motivational variable test have a positive effect because it has a significance value below the level of significance. This shows that motivation is shown to have a positive and significant effect on employee performance. These results show that companies that have high motivation will have good employee performance.

3. There is an incentive effect on employee performance.

The test results of incentive variables have a positive effect because they have a significance value below the level of significance. This shows that incentives are proven to have a positive and significant effect on employee performance. These results show that companies that have high incentives will have good employee performance.

4. There is an influence on organizational commitment, motivation, incentives and together on employee performance.

This can be seen from the ANOVA test, based on the results of the F test, it is proven that the value of $F_{\text {calculated }}$ greater than the $F_{\text {table }}$ of 2,761 and the signification value, below the level of significance, it can be interpreted that the motivation, incentives and commitment of the organization simultaneously affect employee performance.

\section{BIBLIOGRAPHY}

Anwar, P. Mangkunegara (2009), Human Resources Company. Bandung : Teenager Rosdakarya.

Ghozali,Imam. (2011) Application analysis Multivariate with SPSS program. Semarang: Diponegoro University Publishing Body

Hasibuan, Malayu S.P. (2012), Human Resource Management. Jakarta: Bumi Aksara.

Luthans, F. 2006. Organizational behavior. Edition Ten: Yogyakarta: ANDI

Malhotra,Naresh K. (2010), Marketing Research. Jakarta: PT. Index

Mathis, Robert R. \& Jackson, John H. (2012). Human Resource Management. Jakarta : Salemba Four

Nawawi, Hadari. (2008), Human Resource Management for Competitive Business, Yogyakarta: Gajah Mada University Press

Panggabean, Mutiara (2005), Human Resource Management. Jakarta. Ghalia: Indonesia.

Robbins SP \& Judge TA, (2009), Organizational Behavior. Jakarta : Salemba Four

Sarwoto \& Priansa, Donni Juni (2016), HR Management in Public And Business Organizations. Bandung: Alfabeta

Sedamaryanti (2011), Human Resource Management and Work Productivity. Bandung : CV. Mandar 
Forward.

Siagian, Sondang P. (2009), Human Resource Management. Jakarta: Bumi Aksara.

Simamora, Henry (2004), Management

Human Resources Edition III. Yogyakarta : STIE YKPN.

Sugiyono(2013) Qualitative Quantitative Research Methods and R\&D. Bandung: Alfabeta.

Triton, P.B(2010) Riser Parametric Statistics: SPSS13.00 For Windows. Yogyakarta : Andi

Umam, Khaerul (2010), Organizational Behavior. Bandung : Setia Library

Veithzal, Rivai (2010), Human Resource Management. Jakarta: Raja Grafindo Persada.

Werther, Jr., B William \& Davis Keith (2007), Human Resources and Personnel Management. Singapore : McGraw-Hill Inc.

Wirawan, (2009), Evaluation of Human Resource Performance (Theory, Application, and Research). Jakarta: Salemba Four

Wibowo (2016), Performance Management. Edition 5.Jakarta : Rajawali Pers 